\title{
Pengaruh Sumber Protein Berbeda terhadap Laju Alir Pakan, Kecernaan Protein dan Retensi Nitrogen Ayam Lokal Persilangan
}

\author{
The Effect of Different Protein Source on Passage Rate, Protein Digestibility and Nitrogen \\ Retention of Crossbred Local Chicken
}

\author{
Saraswati, U. Atmomarsono dan S. Kismiati \\ Fakultas Peternakan dan Pertanian Universitas Diponegoro \\ Tembalang 50275, Semarang, Indonesia \\ Koresponden e-mail : ssarasswati@gmail.com
}

\begin{abstract}
This research aims to determine the effect different protein source on passage rate, protein digestibility and nitrogen retention of crossbred local chicken. The material used in research were 126 crossbred local chicken (unsexed) of 2 week old with average body weight $129 \pm 6.34 \mathrm{~g}(\mathrm{CV}=5.08 \%)$. The research was conducted using the Completely Randomized Design (CRD) with 3 treatments and 7 replications, there was 21 experimental units with the experimental units consisted of 6 crossbred local chicken. Feedstuffs energy source used in this research are corn and rice bran, and feed supplement $\mathrm{CaCO}_{3}$. Treatments applied were $\mathrm{T} 1$ two protein source (fish meal and soybean meal), T2 three protein sources (fish meal, soybean meal and MBM) and T3 four protein source (fish meal, soybean meal, MBM and PMM). Parameters observed were passage rate, protein digestibility and nitrogen retention. Data were analyzed ANOVA variety of test at the level of 5\%, followed by Duncan test if there is significant effect of the treatment $(\mathrm{P}<0.05)$. The results showed a significant $(\mathrm{P}<0.05)$ on average passage rate and nitrogen, but not significant effects on protein digestibility $(\mathrm{P}>0.05)$. The conclusion of this research showed that the feed materials from the same energy and protein sources that vary can slow feed rate, increase $\mathrm{N}$ retention, but produce the same protein digestibility.
\end{abstract}

Key words : feed different protein source, passage rate, protein digestibility, nitrogen retention, crossbred local chicken.

\begin{abstract}
ABSTRAK
Penelitian ini bertujuan untuk mengevaluasi pengaruh pakan sumber protein berbeda terhadap laju pakan, kecernaan protein dan retensi $\mathrm{N}$ ayam lokal persilangan. Materi yang digunakan dalam penelitian ini adalah 126 ekor ayam lokal persilangan unsexed umur 2 minggu dengan rata-rata bobot badan $129 \pm 6,34 \mathrm{~g}(\mathrm{CV}=5,08 \%)$ dan diberi perlakuan selama 8 minggu. Penelitian dilaksanakan menggunakan metode Rancangan Acak Lengkap (RAL) dengan 3 perlakuan dan 7 ulangan, sehingga terdiri dari 21 unit percobaan dengan masing-masing unit percobaan berisi 6 ekor ayam. Bahan pakan sumber energi yang digunakan adalah jagung dan bekatul sera feed supplement berupa $\mathrm{CaCO}_{3}$. Perlakuan yang dicobakan yaitu: T1 (dua sumber protein, tepung ikan dan bungkil kedelai), T2 (tiga sumber protein (tepung ikan, bungkil kedelai, dan MBM) dan T3 (empat sumber protein (tepung ikan, bungkil kedelai, MBM, dan PMM). Parameter yang diamati adalah laju pakan, kecernaan protein dan retensi nitrogen. Data yang diperoleh dianalisis menggunakan analisis ragam dan diuji dengan uji $\mathrm{F}$ taraf $5 \%$, apabila perlakuan berpengaruh nyata terhadap parameter dilanjutkan dengan uji jarak berganda dari Duncan taraf $5 \%$. Hasil penelitian menunjukkan bahwa perlakuan berpengaruh nyata $(\mathrm{P}<0,05)$ terhadap laju pakan dan retensi $\mathrm{N}$, tetapi tidak berpengaruh nyata $(\mathrm{P}>0,05)$ terhadap kecernaan protein lokal persilangan. Kesimpulan hasil penelitian ini adalah dengan bahan pakan sumber protein yang bervariasi dan sumber energi yang sama dapat memperlambat laju pakan, meningkatkan retensi $\mathrm{N}$, tetapi menghasilkan kecernaan protein yang sama.
\end{abstract}

Kata kunci : pakan sumber protein berbeda, laju pakan, kecernaan protein, retensi N, ayam lokal persilangan.

\section{PENDAHULUAN}

Permintaan ayam lokal semakin meningkat karena citarasa yang dihasilkan lebih diminati oleh masyarakat Indonesia, tetapi produktivitasnya rendah.
Peningkatan produktivitas ayam lokal salah satunya yaitu dengan perbaikan mutu genetik dengan cara melakukan persilangan (Hidayat, 2012). Ayam lokal persilangan merupakan hasil persilangan 
antara ayam ras petelur betina dengan ayam jantan lokal, untuk meningkatkan produktivitas ayam lokal (Fanani et al., 2014). Produktivitas ayam dipengaruhi oleh kualitas pakan, semakin baik kualitas pakan semakin optimal juga produktivitasnya. Faktor yang mempengaruhi produktivitas ayam yaitu imbangan protein dan energi bahan pakan.

Protein adalah salah satu hal terpenting. Pakan dengan protein rendah menyebabkan cepatnya pakan meninggalkan usus, sedangkan pakan dengan protein tinggi akan meninggalkan usus secara perlahan untuk mendapatkan waktu yang lebih banyak untuk denaturasi dan penglarutan protein mentah yang dikonsumsi (Wahju, 2004). Semakin tinggi kandungan protein bahan pakan maka semakin tinggi pula protein yang dikonsumsi sehingga semakin lambat laju pakan di dalam saluran pencernaan ayam serta semakin tinggi pula kecernaan protein dan retensi nitrogen yang dihasilkan.

Tujuan dari penelitian ini adalah mengevaluasi pengaruh pakan sumber protein berbeda terhadap laju pakan, kecernaan protein dan retensi $\mathrm{N}$ ayam lokal persilangan. Manfaat dari penelitian ini adalah dapat memberikan informasi tentang pengaruh bahan pakan sumber protein yang berbeda terhadap laju pakan, kecernaaan protein dan retensi $\mathrm{N}$ ayam lokal persilangan.

\section{MATERI DAN METODE}

Materi yang digunakan dalam penelitian ini adalah 126 ekor ayam lokal persilangan (unsexed umur 2 minggu dengan rata-rata bobot badan $129 \pm 6,34 \mathrm{~g}$ $(\mathrm{CV}=5,08 \%)$. Kandang yang digunakan tipe panggung alas kawat, terdiri dari 21 unit percobaan dengan masing-masing unit percobaan dengan luas ( $1 \times 1 \times 0,125$ meter) berisi 6 ekor ayam. Bahan yang digunakan adalah larutan gula sebesar $2 \%$ untuk DOC yang baru datang, air minum, desinfektan, vitamin, $\mathrm{Fe}_{2} \mathrm{O}_{3}$ untuk indikator pakan penanda dimulainya koleksi ekskreta dan $\mathrm{HCl}$ untuk mengikat $\mathrm{N}$ agar tidak menguap, vaksin yang diberikan yaitu vaksin ND (Newcastle Desease) dan gumboro A.

Bahan pakan sumber energi yang digunakan adalah jagung dan bekatul, bahan pakan sumber protein yang digunakan adalah tepung ikan, bungkil kedelai, MBM (Meat Bone Meal) dan PMM (Poultry Meat Meal), serta feed suplement yang berupa $\mathrm{CaCO}_{3}$. Bahan pakan yang digunakan berbentuk mash dan disajikan secara bebas memilih (satu bahan pakan satu tempat pakan) ad libitum. Alat yang digunakan adalah timbangan digital dengan kapasitas $10 \mathrm{~kg}$ dengan ketelitian $0,001 \mathrm{~kg}$ untuk menimbang pakan dan bobot badan ayam.

Perlakuan yang dicobakan yaitu:

$\mathrm{T} 1$ = dua sumber protein : tepung ikan dan bungkil kedelai.

$\mathrm{T} 2$ = tiga sumber protein : tepung ikan, bungkil kedelai, dan MBM.

$\mathrm{T} 3$ = empat sumber protein: tepung ikan, bungkil kedelai, MBM, dan PMM.

Kandungan nutrisi bahan pakan yang digunakan dalam penelitian dapat dilihat pada Tabel 1. 
e-ISSN 2528-7109

p-ISSN 1978-3000

Tabel 1. Kandungan nutrisi bahan pakan berdasarkan kering udara

\begin{tabular}{|c|c|c|c|c|c|c|c|}
\hline Bahan Pakan & EM & "PK & * SK & Lisin & "Metionin & ${ }^{*} \mathrm{Ca}$ & * $\mathrm{P}$ \\
\hline & (kkal/kg) & ------ & --- & $-(\%)$ & --------- r n n & & \\
\hline Jagung Kuning & 3.796 & 6,54 & 2,15 & 0,34 & 0,21 & 0,03 & 0,20 \\
\hline Bekatul & 3.643 & 10,86 & 7,55 & 0,58 & 0,22 & 0 & 1,53 \\
\hline Bungkil kedelai & 3.213 & 45,76 & 3,97 & 2,98 & 0,70 & 0,05 & 0,39 \\
\hline Tepung ikan & 2.986 & 31,51 & 1,82 & 6,56 & 2,56 & 6,42 & 2,04 \\
\hline MBM & 2.770 & 58,49 & 1,07 & 3,45 & 0,75 & 9,08 & 4,14 \\
\hline PMM & 3.555 & 43,08 & 7,82 & 1,19 & 0,54 & 1,01 & 2,12 \\
\hline $\mathrm{CaCO}_{3}$ & 0 & 0 & 0 & 0 & 0 & 80,00 & 0 \\
\hline
\end{tabular}

Sumber :

*Hasil analisis Proksimat di PT. Sidomuncul, Ungaran (2016).

${ }^{* *}$ Hasil analisisdi Laboratorium Ilmu Nutrisi dan Pakan, Fakultas Peternakan dan Pertanian, Universitas Diponegoro, Semarang (2016).

${ }^{* * * *}$ Hartadi (1980).

${ }^{* * * * *}$ Hasil perhitungan menggunakan Uji Bomb Calorimeter di Laboratorium Ilmu Nutrisi dan Pakan, Fakultas Peternakan dan Pertanian, Universitas Diponegoro, Semarang (2016).

Pengambilan data dilakukan pada akhir penelitian dengan mengambil 2 ekor ayam pada setiap unit percobaan dan dimasukkan ke dalam kandang battery untuk mendapatkan data laju pakan, kecernaan protein dan retensi N. Parameter yang diamati yaitu laju pakan, kecernaan protein dan retensi $\mathrm{N}$.

Pengambilan data laju pakan dengan cara ayam dimasukkan ke dalam kandang battery. Pengukuran dengan menggunakan indikator $\mathrm{Fe}_{2} \mathrm{O}_{3}$ yang dicampur ke dalam pakan sebanyak 0,5\% dari jumlah pakan yang diberikan, menghitung waktu saat ayam makan pertama kali hingga mengeluarkan ekskreta sesuai warna indikator (Sholeh $e t$ al., 2012).

Pengambilan data kecernaan protein dan retensi $\mathrm{N}$ dengan cara ayam lokal persilangan diberi pakan yang diberi indikator $\left(\mathrm{Fe}_{2} \mathrm{O}_{3}\right)$, kemudian total koleksi dilakukan selama 2 hari. Menghitung kecernaan dengan menggunakan rumus menurut Anggorodi (1995):

$$
\text { Kecernaan Protein }=\frac{(\Sigma \text { konsumsi pakan } \mathrm{x} \% \text { PK pakan })-(\Sigma \text { ekskreta } \mathrm{PK} \text { ekskreta })}{\Sigma \text { konsumsi pakan } \mathrm{x} \% \mathrm{PK} \text { pakan }} \times 100 \%
$$

\section{Pengambilan Data Retensi Nitrogen}

Menghitung retensi nitrogen dengan menggunakan rumus menurut Sudrajat et al. (2015) sebagai berikut:

Retensi Nitrogen $=($ konsumsi pakan $\mathrm{x}$ nitrogen pakan $)-($ berat ekskreta $\mathrm{x}$ nitrogen ekskreta $)$. 


\section{HASIL DAN PEMBAHASAN}

Hasil penelitian pengaruh pakan sumber protein terhadap laju pakan, kecernaan protein dan retensi $\mathrm{N}$ ayam lokal persilangan dapat dilihat pada Tabel 2.

Tabel 2. Rata-rata hasil laju pakan, kecernaan protein dan retensi $\mathrm{N}$ ayam lokal persilangan

\begin{tabular}{lccc}
\hline \multirow{2}{*}{ Parameter } & \multicolumn{3}{c}{ Perlakuan } \\
\cline { 2 - 4 } & $\mathrm{T} 1$ & $\mathrm{~T} 2$ & $\mathrm{~T} 3$ \\
\hline Laju pakan (menit/ekor) & $224,19^{\mathrm{b}}$ & $251,31^{\mathrm{a}}$ & $252,43^{\mathrm{a}}$ \\
Kecernaan protein (\%/ekor) & 75,93 & 76,33 & 78,10 \\
Retensi nitrogen (g/ekor) & $1,15^{\mathrm{b}}$ & $1,18^{\mathrm{b}}$ & $1,61^{\mathrm{a}}$ \\
\hline
\end{tabular}

Keterangan: Superskrip yang berbeda pada baris yang sama menunjukkan berpengaruh nyata $(\mathrm{P}<0,05)$.

\section{Laju Pakan}

Berdasarkan hasil penelitian pengaruh perlakuan terhadap laju pakan ayam lokal persilangan umur 10 minggu dapat dilihat pada Tabel 2. Hasil laju pakan menunjukkan bahwa masih berada dalam kisaran normal karena sesuai dengan penelitian Prawitasari et al. (2012) bahwa laju pakan pada ayam bukan ras selama 296,82 menit. Pendapat Schaible dan Patrick (1980) menyatakan bahwa laju pakan pada unggas berkisar antara 120 240 menit.

Hasil penelitian analisis ragam menunjukkan bahwa perlakuan berpengaruh nyata $(\mathrm{P}<0,05)$ terhadap laju pakan ayam lokal persilangan. Hasil perlakuan menunjukkan bahwa T2 tidak berpengaruh nyata terhadap $\mathrm{T} 3$, tetapi $\mathrm{T} 1$ berpengaruh nyata terhadap $\mathrm{T} 2$ dan $\mathrm{T} 3$. Laju pakan pada T3 lebih tinggi dikarenakan semakin bervariasi sumber protein dan kandungan asam amino maka semakin tinggi nilai biologis protein tersebut. Tinggi rendahnya nilai biologis protein tergantung dari jumlah, macam dan imbangan asam amino essensial yang menyusunnya. Semakin banyak macam bahan pakan sumber protein maka semakin seimbang imbangan asam amino yang menyusunnya, sehingga semakin tinggi pula nilai biologis protein tersebut. Hal ini disebabkan karena adanya pengaruh saling melengkapi dari berbagai macam protein. (Zuprizal dan Kamal, 2005). Menurut Hughes (2004), faktor yang mempengaruhi laju pakan yaitu kandungan nutrisi dan bentuk fisik bahan pakan.

Pemberian pakan dengan variasi pakan dan sumber protein yang berbeda antar perlakuan menghasilkan laju pakan yang berbeda juga. Semakin tinggi kandungan protein bahan pakan maka semakin lambat pula laju pakannya. Menurut penelitian Wahju (2004), pakan dengan protein rendah menyebabkan cepatnya pakan meninggalkan usus, sedangkan pakan dengan protein tinggi akan meninggalkan usus secara perlahan untuk mendapatkan waktu yang lebih banyak untuk denaturasi dan penglarutan protein mentah yang dikonsumsi. Menurut penelitian Irawan et al. (2012), lamanya laju pakan di dalam saluran pencernaan ayam dipengaruhi oleh variasi jenis pakan yang beragam maupun konsumsi pakan pada masing-masing perlakuan, semakin tinggi kandungan protein dalam pakan maka laju pakan akan semakin lama pula. Perbedaan laju pakan dipengaruhi oleh kualitas bahan pakan yang dikonsumsi. Penelitian Setyanto et al. (2012), laju pakan dipengaruhi oleh kualitas pakan, konsumsi pakan, imbangan energi dan 
protein serta volume pakan didalam lambung. Semakin perlahan laju pakan pada ayam maka semakin baik pakan dicerna di dalam tubuh sehingga kecernaan semakin baik pula.

\section{Kecernaan Protein}

Berdasarkan hasil penelitian pengaruh perlakuan terhadap kecernaan protein dapat dilihat pada Tabel 2. Nilai kecernaan protein berada dalam kisaran normal. Hal ini sesuai pendapat Wahju (2004) bahwa kecernaan protein yang terdapat di dalam protein pakan penyusun ransum pakan unggas yaitu berkisar antara 75-90\%.

Hasil analisis ragam menunjukkan bahwa perlakuan tidak berpengaruh nyata $(\mathrm{P}>0,05)$ terhadap kecernaan protein ayam lokal persilangan. Pemberian pakan dengan sumber protein yang bervariasi pada masing-masing perlakuan terhadap kecernaan protein tidak berpengaruh nyata tetapi memiliki nilai kecernaan protein dalam kisaran normal. Hal ini sesuai dengan pendapat Ariesta et al. (2015) bahwa nilai kecernaan protein tidak berpengaruh tetapi protein yang tercerna akan meningkat dengan meningkatnya kandungan protein bahan pakan.

Suatu bahan pakan sumber protein dikatakan berkualitas baik apabila persentase protein tercerna tinggi sehingga mencukupi kebutuhan sintesis protein karena adanya satu atau lebih asam amino ensensial yang berarti sebagian besar kandungan proteinnya dapat dimanfaatkan oleh ternak (Wahju, 2004). Menurut penelitian Hernandes et al. (2004), kecernaan protein dipengaruhi oleh kandungan energi dan kandungan protein. Kecernaan bahan pakan yang tinggi menunjukkan sebagian besar dari zat-zat makanan yang terkandung di dalamnya dapat dimanfaatkan oleh ternak (Situmorang et al., 2013). Penelitian Prawitasari et al. (2012) bahwa faktor yang mempengaruhi kecernaan protein adalah kandungan protein pada pakan, semakin tinggi protein yang terkandung dalam pakan maka semakin tinggi konsumsi proteinnya sehingga nilai kecernaan protein akan tinggi pula. Tinggi rendahnya kecernaan protein tergantung pada kandungan protein bahan pakan dan banyaknya protein yang masuk dalam saluran pecernaan (Tilman et al.,1998). Menurut penelitian Pishnamazi et al. (2005), nilai kecernaan dipengaruhi oleh kandungan dan kualitas bahan pakan. Kecernaan protein dipengaruhi oleh kualitas protein, kandungan nitrogen dan asam amino bahan pakan (Saki et al., 2010).

\section{Retensi N}

Hasil penelitian pengaruh perlakuan terhadap retensi $\mathrm{N}$ dapat dilihat pada Tabel 2. Nilai retensi $\mathrm{N}$ termasuk tinggi. Menurut penelitian Fanani et al. (2014) bahwa nilai retensi $\mathrm{N}$ pada ayam lokal persilangan (ayam lokal jantan dengan ayam niaga petelur betina) yaitu 1,3 gram. Penelitian Ma'rifah et al. (2013) menyatakan bahwa nilai retensi $\mathrm{N}$ persilangan antara ayam lokal jantan dengan ayam petelur betina adalah 1,11 gram.

Hasil analisis ragam menunjukkan bahwa pengaruh pemberian pakan sumber protein berbeda berpengaruh nyata $(\mathrm{P}<0,05)$ terhadap parameter retensi $\mathrm{N}$ ayam persilangan lokal. T1 tidak berpengaruh nyata terhadap $\mathrm{T} 2$, tetapi $\mathrm{T} 1$ dan T2 berpengaruh nyata terhadap T3. Berdasarkan preferensi T1 lebih banyak mengkonsumsi tepung ikan $(7,77 \%)$ dan bungkil kedelai $(8,70 \%)$ dibanding $\mathrm{T} 2$. 
Tepung ikan merupakan bahan pakan sumber protein hewani yang sangat baik. Menurut penelitian Sitompul (2004) bahwa tepung ikan dan bungkil kedelai merupakan pakan sumber protein utama untuk ayam karena mengandung protein yang tinggi. Menurut pendapat Wahju (2004), tepung ikan adalah pakan sumber protein yang mengandung asam amino ensensial dan sumber utama lisin dan metionin yang sangat bagus untuk kebutuhan ayam.

Perbedaan nilai retensi $\mathrm{N}$ pada setiap perlakuan dipengaruhi oleh nilai kandungan nutrisi dan energi di dalam bahan pakan. Semakin tinggi kandungan protein bahan paka maka akan semakin tinggi pula nilai retensi N. Menurut Mahfudz et al. (2010), nilai retensi nitrogen dipengaruhi oleh kandungan energi pakan.

Menurut Resnawati (2006), kandungan nutrisi dan energi suatu bahan pakan akan mempengaruhi nilai retensi N. Menurut penelitian Fanani et al. (2014), peningkatan retensi nitrogen merupakan salah satu indikasi bahwa protein yang tercerna semakin banyak. Menurut Maghfiroh et al. (2012), banyaknya protein yang dapat diserap oleh tubuh mengakibatkan tubuh ayam memiliki kesempatan untuk meretensi nitrogen lebih banyak.

\section{KESIMPULAN}

Berdasarkan hasil penelitian dapat disimpulkan bahwa dengan bahan pakan sumber protein yang bervariasi dan sumber energi yang sama dapat memperlambat laju pakan, meningkatkan retensi $\mathrm{N}$, tetapi menghasilkan kecernaan protein yang sama.

\section{DAFTAR PUSTAKA}

Ariesta, A. H., I. G. Mahardika dan G. A. M. K. Dewi. 2015. Pengaruh Level Energi dan Protein Ransum terhadap Penampilan Ayam Kampung Umur 0-10 Minggu. Majalah Ilmu Peternakan. 18 (3): 89 - 94.

Fanani, A. F., N. Suthama dan B. Sukamto. 2014. Retensi nitrogen dan konversi pakan ayam lokal persilangan yang diberi ekstrak umbi dahlia (Dahlia variabilis) sebagai sumber inulin. J. Sains Peternakan. 12(2): 69-75.

Hernandez, F., J. Madrid, V. Garcia, J. Orengo dan M. D. Megias. 2004. Influence of two plant extracts on broilers performance digestibility, and digestive organ size. Poult. Sci. $83: 169-174$.

Hughes, R. J. 2004. The rate of passage of digesta influences energy metabolism in broiler chickens. Aust. Poult. Sci. Sym. 16: $63-66$.

Irawan, I., D. Sunarti, dan L. D. Mahfudz. 2012. Pengaruh pemberian pakan bebas pilih terhadap kecernaan protein burung puyuh (Coturnix coturnix japonica). Anim. Agric. J. 1(2): $238-245$.

Maghfiroh, K., I. Mangisah, dan V. D. Y. B. Ismadi. 2012. Pengaruh penambahan sari jeruk nipis (Citrus aurantifolia) dalam ransum terhadap kecernaan protein kasar dan retensi nitrogen pada itik magelang jantan. Anim. Agric. J. 1 (1) : 669 - 683.

Mahfudz, L. D., U. Atmomarsono, D. Sunarti, E. Suprijatna dan T. A. Sarjana. 2011. Protein consumption 
and efficiency of Kedu, Arab and crossing chickens fed diets with different protein levels. Egypt Poult. Sci. 31 (2) : 491- 500.

Ma'rifah, B., U. Atmomarsono dan N. Suthama. 2013. Nitrogen retention and productive performance of crossbred native chicken due to feeding effect of kayambang (Salvinia molesta). Int. J. Sci. and Eng. 5(1): 19-24.

Pishnamazi, A., J. Pourreza., M.A. Edriss., and A.H. Samie. 2005. Influence of broiler breeder and laying hen breed on the apparent metabolizable energy of selected feed ingredients. International Journal of Poultry Science 4 (3): 163-166.

Prawitasari, R. H., V. D. Y. B. Ismadi dan I. Estiningdriati. 2012. Kecernaan protein kasar dan serat kasar serta laju digesta pada ayam Arab yang diberi ransum dengan berbagai level Azolla microphylla. Anim. Agric. J. 1 (1): 471-483.

Resnawati, H. 2006. Retensi nitrogen dan energi metabolis ransum yang mengandung cacing tanah (Lumbricus rubellus) pada ayam pedaging. Seminar Nasional Teknologi Peternakan dan Veteran. Bogor, 5-6 September 2006. Balai Penelitian Ternak, Bogor. 661 - 667.

Saki, A. A., S. Mirzayi, S. H. Ghazi, M. M. Moini dan R. N. Harsini. 2010. Amino acids and protein digestibility and metabolizable energy cavailability of barley ration in response to grind enzyme in broiler chickens. Asian. Aust. J. Anim. Sci. 23 (5): $614-621$.
Schaible, A. J dan H. Patrick. 1980. Poultry Feeds and Nutrition. $2^{\text {nd }}$ Ed. The Avi Publising Company, INC, Westport.

Setyanto, A., U. Atmomarsono dan R. Muryani. 2012. Pengaruh penggunaan tepung jahe emprit (Zingiber officinale var Amarum) dalam ransum terhadap laju pakan, dan kecernaan pakan ayam kampung umur 12 minggu. J. Anim. Agric. 1 (1): $711-720$.

Sitompul, S. 2004. Analisis Asam Amino dalam Tepung Ikan dan Bungkil Kedelai. Buletin Teknik Pertanian. 9 (1): $33-37$.

Situmorang, N. A., L. D. Mahfudz dan U. Atmomarsono. 2013. Pengaruh pemberian tepung rumput laut (Gracilaria verrucosa) dalam ransum terhadap efisiensi penggunaan protein ayam broiler. Anim. Agri. J. 2(2) : $49-56$.

Tillman, A. D., H. Hartadi, S. Reksohadiprodjo, S. Prawirokusumo dan S. Lebdosoekojo. 1998. Ilmu Makanan Ternak Dasar. Gadjah Mada University Press, Yogyakarta.

Wahju, J. 2004. Ilmu Nutrisi Unggas. Edisi 4. Gadjah Mada University Press, Yogyakarta.

Zuprizal dan Kamal. 2005. Nutrisi Dan Ransum Unggas. Universitas Gadja Mada Press. Yogyakarta 